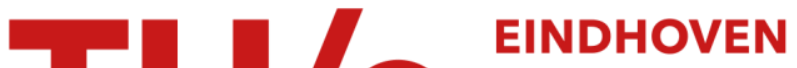 UNIVERSITY OF TECHNOLOGY
}

\section{Opportunities of atomic layer deposition for perovskite solar cells}

Citation for published version (APA):

Zardetto, V., Di Giacomo, F., Mohammed, M. A., Lucarelli, G., Razza, S., D’Epifanio, A., Licoccia, S., Kessels, W. M. M., Di Carlo, A., Brown, T. M., \& Creatore, M. (2015). Opportunities of atomic layer deposition for perovskite solar cells. ECS Transactions, 69(7), 15-22. https://doi.org/10.1149/06907.0015ecst

DOI:

10.1149/06907.0015ecst

Document status and date:

Published: 02/10/2015

\section{Document Version:}

Publisher's PDF, also known as Version of Record (includes final page, issue and volume numbers)

\section{Please check the document version of this publication:}

- A submitted manuscript is the version of the article upon submission and before peer-review. There can be important differences between the submitted version and the official published version of record. People interested in the research are advised to contact the author for the final version of the publication, or visit the $\mathrm{DOI}$ to the publisher's website.

- The final author version and the galley proof are versions of the publication after peer review.

- The final published version features the final layout of the paper including the volume, issue and page numbers.

Link to publication

\section{General rights}

Copyright and moral rights for the publications made accessible in the public portal are retained by the authors and/or other copyright owners and it is a condition of accessing publications that users recognise and abide by the legal requirements associated with these rights.

- Users may download and print one copy of any publication from the public portal for the purpose of private study or research.

- You may not further distribute the material or use it for any profit-making activity or commercial gain

- You may freely distribute the URL identifying the publication in the public portal.

If the publication is distributed under the terms of Article 25fa of the Dutch Copyright Act, indicated by the "Taverne" license above, please follow below link for the End User Agreement:

www.tue.nl/taverne

Take down policy

If you believe that this document breaches copyright please contact us at:

openaccess@tue.nl

providing details and we will investigate your claim. 


\title{
Opportunities of Atomic Layer Deposition for Perovskite Solar Cells
}

\author{
V. Zardetto ${ }^{\text {a,b }}$, F. Di Giacomo ${ }^{\mathrm{c}}$, M.A. Mohammed ${ }^{\mathrm{a}}$, G. Lucarelli ${ }^{\mathrm{c}}$, S.Razza $^{\mathrm{c}}$, A.

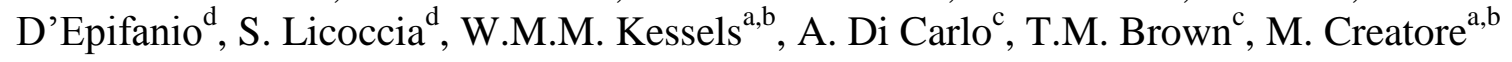 \\ ${ }^{a}$ Department of Applied Physics, Eindhoven University of Technology, P.O. Box 513, \\ 5600 MB Eindhoven, The Netherlands. \\ ${ }^{\mathrm{b}}$ Solliance, High Tech Campus 21, 5656 AE Eindhoven, The Netherlands \\ ${ }^{c}$ CHOSE - Centre for Hybrid and Organic Solar Energy, Department of Electronic \\ Engineering, University of Rome "Tor Vergata", 00133 Rome, Italy. \\ 'Department of Chemical Science and Technologies, University of Rome "Tor Vergata", \\ 00133 Rome, Italy
}

The fabrication of different functional layers by means of atomic layer deposition is proposed for the novel organo-lead halide perovskite solar cells. A plasma- assisted process at $150{ }^{\circ} \mathrm{C}$ was adopted to deposit an efficient $\mathrm{TiO}_{2}$ compact blocking layer on ITO-polymer substrates. Efficient flexible devices were obtained already with layers as thin as $10 \mathrm{~nm}$. A Thermal ALD $\mathrm{Al}_{2} \mathrm{O}_{3}$ process at $150{ }^{\circ} \mathrm{C}$ was successfully applied on a mesoscopic anatase $\mathrm{TiO}_{2}$ structure: an improvement of the overall performance of the solar cell $(+13 \%)$ was measured with only 1 ALD cycle compared to devices without over-layer. Interestingly, a drastic reduction of the performance was observed when increasing the number of the cycles.

\section{Introduction}

Atomic Layer Deposition (ALD) is nowadays extensively adopted in photovoltaics (PV) due to the accurate control in film thickness and composition, as well as the high deposition conformality and uniformity (1). Ultra-thin $\mathrm{ALD} \mathrm{Al}_{2} \mathrm{O}_{3}$ layers have been successfully applied on the surface of crystalline silicon as excellent passivation layers (2). In copper indium gallium (di) selenide (CIGS) solar cells, ALD (Zn,Mg)O and $\mathrm{Zn}(\mathrm{O}, \mathrm{S})$ have been deposited for the development of cadmium-free buffer layers for the window top contact (3). Recently, the outbreak of organo-lead (mixed) halide perovskite absorbers $\left(\mathrm{CH}_{3} \mathrm{NH}_{3} \mathrm{PbI}_{3-\mathrm{x}} \mathrm{Y}_{\mathrm{x}}, \mathrm{Y}=\mathrm{Br}, \mathrm{Cl}\right)$ has attracted a huge interest in the photovoltaic community due to the remarkable increase in the last 3 years of the device performance and the easy solution manufacturing steps. In addition to that, the wide and tunable band gap of this material makes it very promising for the fabrication of a top cell in a tandem junction configuration with crystalline silicon or CIGS as bottom devices (4). Although different structures have been proposed in literature, the most efficient and most stable perovskite solar cells consist of a complex 3D structure, generally a mesoporous $\mathrm{TiO}_{2}$, to ensure an efficient light harvesting and an effective photo-generated carrier extraction and collection (5). The precise control on the large surface area and the several interfaces present in this architecture represents a fundamental strategy to reduce/suppress the charge carrier recombination processes which affect the final device performance (Figure 1). In general, two main recombination mechanisms can be identified: 1) a charge 
transfer process at the interface between the transparent conductive oxide (TCO) and the perovskite (which acts also as hole conductor) or the hole transport layer (HTM) 2) the charge transfer process at the interface between the mesoporous $\mathrm{TiO}_{2}$ film and the perovskite or the HTM (see Figure 1b).

Deposition of different metal oxide films via solution processed techniques appears in literature as the common method to achieve efficient devices (6-9). The high quality of the layers deposited via ALD and the precise control of the thicknesses also on structures with high aspect ratio such as in electronics and batteries applications (10), makes this technique a valid alternative for this new class of solar cells. Thus, in this work two different ALD layers were adopted to control the recombination mechanisms at the interfaces.

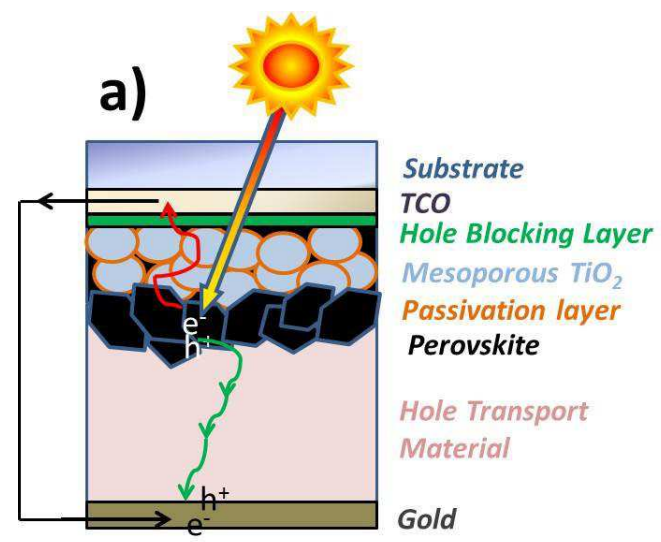

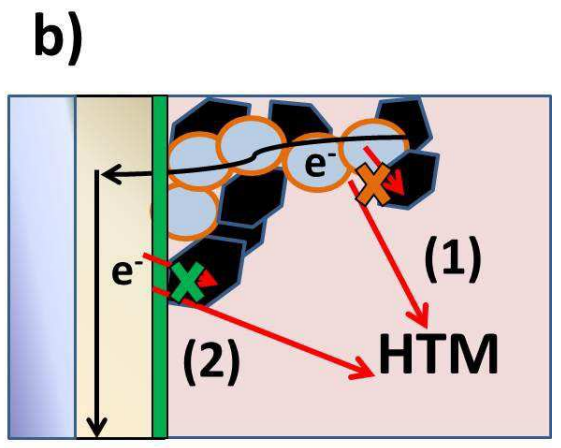

(1) Back reaction via $\mathrm{TiO}_{2}$

(2) Back reaction via TCO

Figure 1: a) Schematic representation of the architecture of a mesostructured perovskite solar cell; b) Schematics of the two main recombination pathways in the device and the deposition of a compact blocking layer on the TCO and a passivation layer on the $\mathrm{TiO}_{2}$ mesoporous structure.

\section{Atomic Layer Deposition of Blocking Layers on Transparent Conductive Oxides}

The conventional approach to control the interface between the TCO and the hole conductor layers (perovskite and HTM) consists in the deposition of a $\mathrm{TiO}_{2}$ compact layer on top of the TCO surface. This layer should be extremely compact, without pinholes and exhibit rectification characteristics. Spray pyrolysis technique is a simple method typically reported in literature to deposit 50-100 nm of $\mathrm{TiO}_{2}$ layer on $\mathrm{FTO} / \mathrm{glass}$ substrates $(6,11)$. The deposition occurs at high temperatures $\left(450{ }^{\circ} \mathrm{C}\right)$ to allow the pyrolysis of the titanium precursor and the evaporation of the solvents (11). Recently, ALD process has been successfully adopted in glass-based perovskite solar cells, depositing $50 \mathrm{~nm}$ of titanium dioxide at $200{ }^{\circ} \mathrm{C}$ using tetrakis(dimethylamino) titanium (TDMAT) and $\mathrm{H}_{2} \mathrm{O}$ precursors. The ALD layer exceeds the performance of devices with spray pyrolysis and sol-gel processes due to lower density of nanoscale defects and pinholes (12).

Plasma-assisted ALD can offer several advantages with respect to the conventional thermal approach (13). The fabrication of higher quality films in terms of density and materials properties in the range of processing temperatures compatible with conductive polymer substrates, is extremely attractive due to the potential development of high throughput, roll-to-roll manufacturing processes (14). In the first part of this contribution, 
we show the effect of a plasma assisted $\mathrm{ALD} \mathrm{TiO}_{2}$ layer and the role of the thickness for an efficient compact blocking layer for flexible devices on ITO/PET substrates.

\section{Atomic Layer Deposition for Passivation Layers on Mesoporous Structures}

The strategy for the suppression/reduction of the recombination mechanisms at the interface between the mesoporous $\mathrm{TiO}_{2}$ layer and the perovskite/HTM is the natural evolution of the approach followed in the dye-sensitized solar cell (DSC) technology. Here, solution processed $\mathrm{TiO}_{2}$ (7), or thin wide band gap metal oxides such as $\mathrm{Al}_{2} \mathrm{O}_{3}$, $\mathrm{MgO}, \mathrm{ZrO}_{2}(15,16)$ were successfully adopted, with the main consequence of an enhancement of the overall performance. In the last 6 years also different ultra-thin ALD layers $\left(\mathrm{Al}_{2} \mathrm{O}_{3}, \mathrm{HfO}_{2}, \mathrm{Ga}_{2} \mathrm{O}_{3}\right)$ were tested in the DSC architectures (17-20), The choice of ALD was driven by the assumption that the precise control of the oxide film thickness plays a key role to provide an efficient passivation without any detrimental effect on the electron extraction from the dye molecules. Interestingly, while a passivation layer with a thickness in the nm-range is claimed to work for solution processed metal oxide coatings, a sub-nm thick ALD layer is sufficient to passivate the mesoscopic structure $(15,18)$. For organo-lead halide solar cells, only sol-gel metal oxides have been applied $(8,9)$. In the second part of this work we describe the effect of an $\mathrm{Al}_{2} \mathrm{O}_{3}$ passivation layer on the mesoporous $\mathrm{TiO}_{2}$ structure.

\section{Experimental details}

The $\mathrm{TiO}_{2}$ compact layers were deposited on conductive substrate (ITO-PET) at 150 ${ }^{\circ} \mathrm{C}$ in a thermal and remote plasma reactor (FlexAL ${ }^{\mathrm{TM}}$ ) using heteroleptic dimethylamido precursor with a methylcyclopentadienyl ligand $\left(\mathrm{Ti}\left(\mathrm{Cp}^{\mathrm{Me}}\right)\left(\mathrm{NMe}_{2}\right)_{3}\right.$ an $\mathrm{O}_{2}$ inductively coupled plasma. Details and specifications of the ALD process have been extensively discussed in (22). A -plasma treatment $(200 \mathrm{~W})$ of 3 min was performed prior to the ALD deposition. The $\mathrm{Al}_{2} \mathrm{O}_{3}$ passivation layer was deposited on the mesoporous $\mathrm{TiO}_{2}$ film at $150{ }^{\circ} \mathrm{C}$ in a thermal and remote plasma reactor $\left(\mathrm{OpAl}^{\mathrm{TM}}\right)$ at $150{ }^{\circ} \mathrm{C}$. Trimethyaluminum (TMA) precursor was dosed for $40 \mathrm{~ms}$ and $\mathrm{H}_{2} \mathrm{O}$ vapour for $250 \mathrm{~ms}$. Purges times between the precursors was kept at $20 \mathrm{~s}$ in order to suppress any CVD contribution to the growth.

The film thickness was determined using a J.A. Woollam, Inc. M2000U (0.75-5.0 eV) spectroscopic ellipsometer (SE). XPS (Thermo Scientific K-Alpha) depth profile measurements were acquired alternating narrow-scan measurements and sputtering with argon ions. TEM (FEI Tecnai $300 \mathrm{kV}$ ) in HAADF scanning mode was carried out to evaluate the conformity and the thickness of the $\mathrm{Al}_{2} \mathrm{O}_{3}$ layer on the $\mathrm{TiO}_{2}$ nanoparticles.

Flexible perovskite solar cells were fabricated with the following architecture: PET / ITO / Compact-ALD $\mathrm{TiO}_{2} /$ mesoporous-TiO ${ }_{2}$-scaffold / $\mathrm{CH}_{3} \mathrm{NH}_{3} \mathrm{PbI}_{3-\mathrm{x}} \mathrm{Cl}_{\mathrm{x}} /$ Spiro OMeTAD / Au. Details on the fabrication of the several layers apart from the ALD $\mathrm{TiO}_{2}$ were reported in (23). Glass perovskite solar cells were fabricated with the following structure: Glass / FTO / Compact- $\mathrm{TiO}_{2} /$ mesoporous- $\mathrm{TiO}_{2}$-scaffold / $\left(\mathrm{ALD}-\mathrm{Al}_{2} \mathrm{O}_{3}\right)$ / $\mathrm{CH}_{3} \mathrm{NH}_{3} \mathrm{PbI}_{3-\mathrm{x}} \mathrm{Cl}_{\mathrm{x}} /$ Spiro OMeTAD / Au. Details on the deposition of the several layers except for the ALD layers are given in (24). Class A solar simulator (ABET Sun 2000) at AM1.5 and $100 \mathrm{~mW} \mathrm{~cm}^{-2}$ illumination conditions calibrated with a reference silicon cell 
was used to measure the current voltage curves and the photovoltaic parameters of the devices.

\section{Results and Discussion}

The efficiencies of the flexible perovskite solar cells as a function of the ALD number of cycles and the thickness are reported in Fig.2. $\mathrm{TiO}_{2}$ thickness has been calculated by the growth per cycle measured on the silicon reference wafer, i.e. $0.055 \mathrm{~nm} /$ cycle. The absence of the compact layer leads to extremely poor performance of the cell $(\eta=0.02 \%)$. The efficiencies start to increase already with a thin film of $5.5 \mathrm{~nm}$ (100 ALD cycles) achieving a maximum around $11 \mathrm{~nm}$. After this value, a slight decrease (up to $42 \mathrm{~nm}$ ) is observed. Higher performance devices (7-8\%) with $11 \mathrm{~nm}$ of $\mathrm{TiO}_{2}$ have been obtained using the same process in different experimental batches (23). Differently from the thick solution processed films reported in literature $(50-100 \mathrm{~nm})$, flexible perovskite devices work properly also with a thinner ALD compact $\mathrm{TiO}_{2}$ layers.

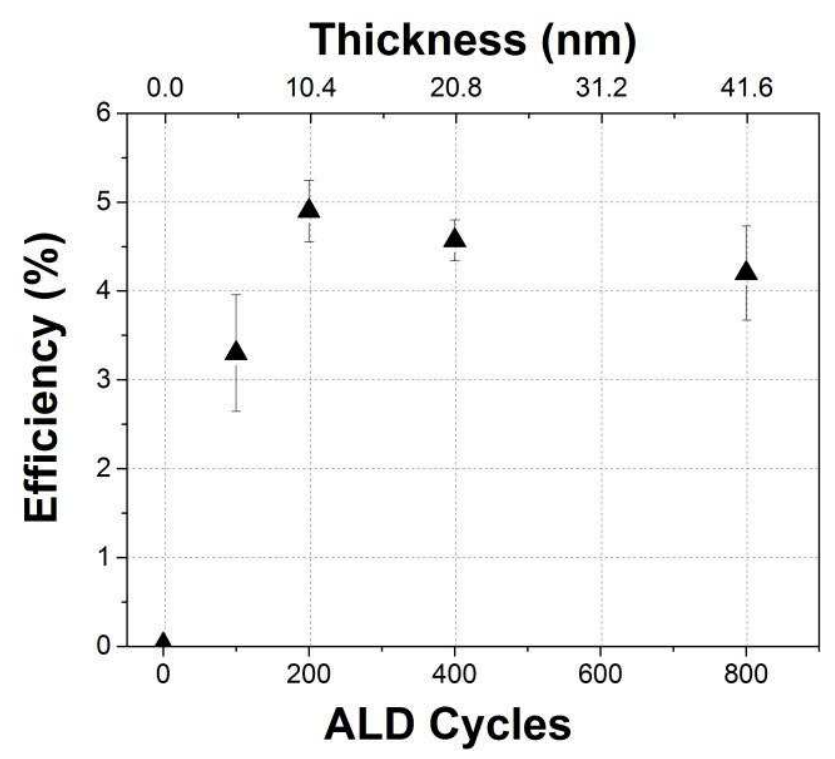

Figure 2. Photovoltaic efficiencies for perovskite based solar cells as a function of $\mathrm{TiO}_{2}$ ALD thickness.

The importance of the interface control in this technology emerges by the analysis of the current density-voltage (JV) dark curves as depicted in Fig.3a where the logarithmic representation (Tafel plot) has been used. When $\mathrm{TiO}_{2}$ is not deposited on the ITO surface, the symmetric JV curve indicates no diode like behavior. The calculated exchange current density value, $\mathrm{J}_{0}$, at the interface ITO/perovskite is extremely high $\left(3 \mathrm{~mA} \mathrm{~cm}{ }^{-2}\right)$. The introduction of $\mathrm{TiO}_{2}$ compact layer immediately has a significant impact on the JV dark current behavior, with the development of a rectifying behavior even for the thinnest $\mathrm{TiO}_{2}$. As a consequence of that, the value of $\mathrm{J}_{0}$ is reduced of three order of magnitude, $\left(0.2-0.7 \mu \mathrm{Acm}^{-2}\right.$ ) as well the reverse dark current (maximum value at $0.1 \mathrm{mAcm}^{-2}$ for $-1 \mathrm{~V})$. In the low positive voltage range where the forward dark current is governed by shunting mechanism (25), a drastic decrease is also detected. Interestingly, the reduction follows the number of the cycles. For voltages $>0.5 \mathrm{~V}$, JV curves show a steep increment which is ascribed to a diffusion-dominated current (25). As expected, no difference in slope is evident apart at higher voltages, where change in slope can appear due to the contribution of series resistance, likely related in this case to variations in the ITO sheet resistance. 


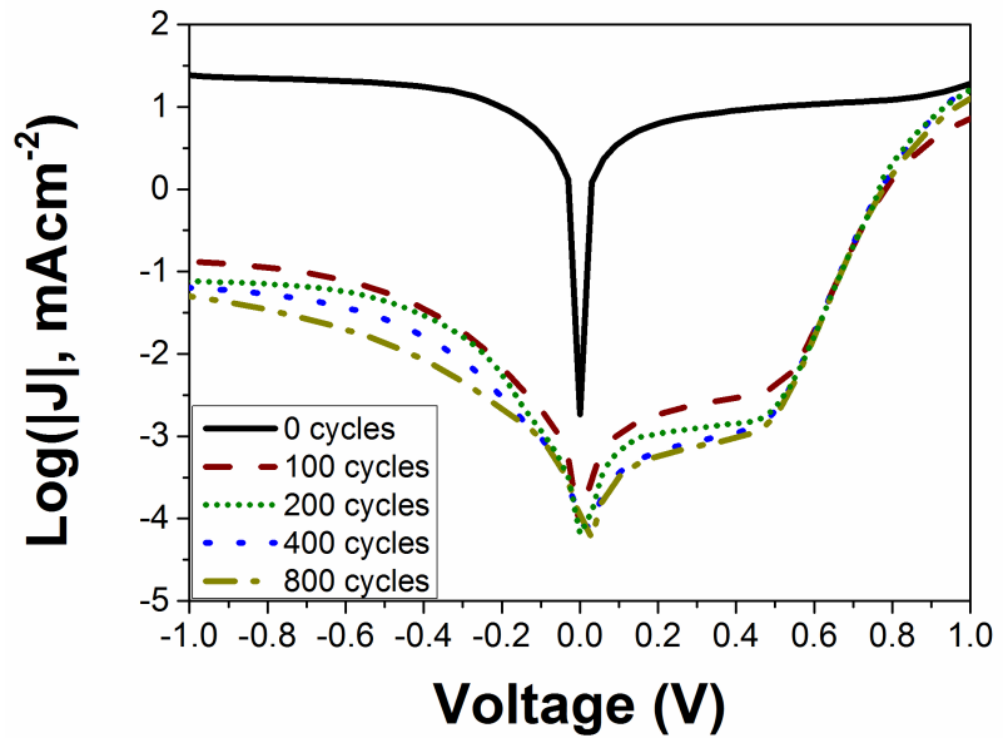

Figure 3. J-V dark current curves for perovskite based solar cells with different ALD cycles (i.e. thickness) of the $\mathrm{TiO}_{2}$ compact layer.

In order to control the second recombination interface between the mesoporous $\mathrm{TiO}_{2}$ film and the hole conductors (the perovskite absorber and the hole transport material), the deposition of an ultrathin $\mathrm{Al}_{2} \mathrm{O}_{3}$ layer is adopted. In Fig.4, a high resolution-TEM micrograph shows a conformal amorphous $\mathrm{Al}_{2} \mathrm{O}_{3}$ layer on crystalline $\mathrm{TiO}_{2}$ nanoparticles. TEM analysis shows a growth per cycle (GPC) of $0.1 \mathrm{~nm} /$ cycle at $150{ }^{\circ} \mathrm{C}$ which matches with the GPC values measured on the reference silicon wafer. This result points out the accurate control of the thickness for ALD processes also in complex 3D structures, such as mesoporous layers.

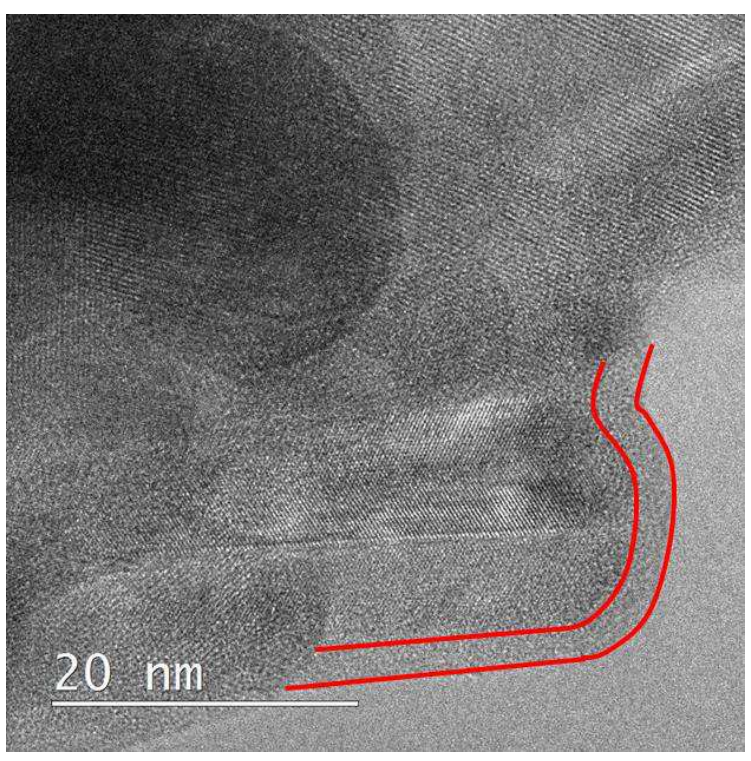

Figure 4: High resolution-TEM micrograph of thermal ALD $\mathrm{Al}_{2} \mathrm{O}_{3}$ on a nanocrystalline $\mathrm{TiO}_{2}$ mesoporous film. The lines serve as a guide to the eye. 
XPS depth profile measurement was used as efficient tool to investigate the distribution of $\mathrm{Al}$ within the mesocoscopic $\mathrm{TiO}_{2}$ film. This is a fundamental requirement to ensure the complete passivation of the complex $\mathrm{TiO}_{2}$ surface. The result in Fig. 5 highlights the homogeneous content of [Al] in respect to [Ti].

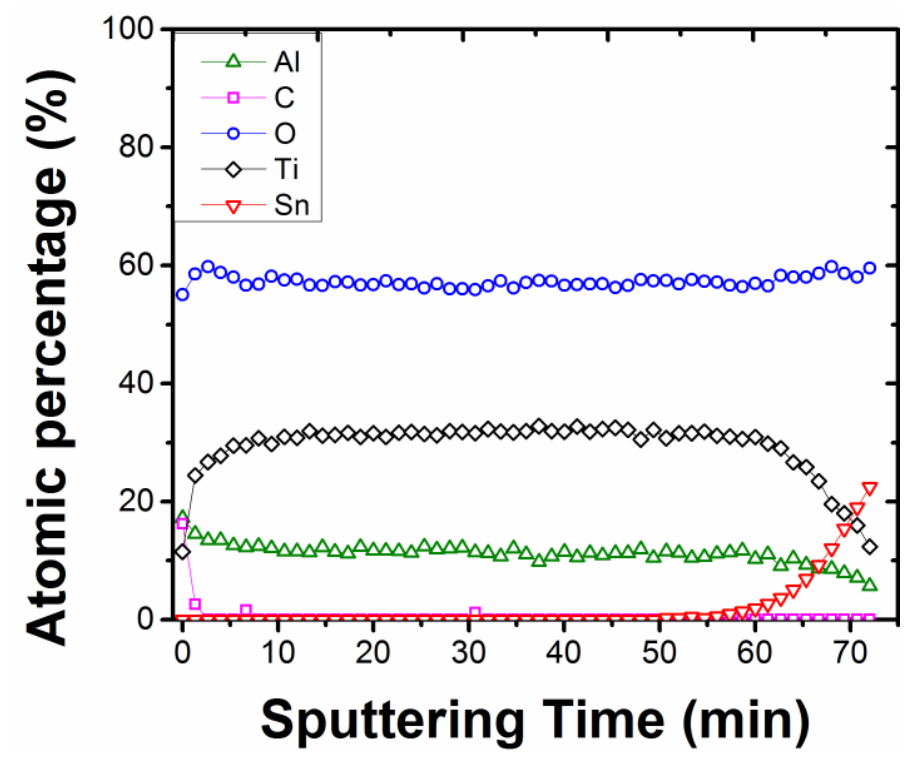

Figure 5. Atomic concentration (\%) as a function of sputtering time for $600 \mathrm{~nm}$ mesoporous $\mathrm{TiO}_{2}$ layer on conventional $\mathrm{FTO} /$ glass substrate with 20 cycles of $\mathrm{Al}_{2} \mathrm{O}_{3}$ deposited via ALD.

The role of the overlayer thickness on the final performance of the perovskite solar cell was investigated, and the results are summarized in Table I.

The deposition of just one $\mathrm{Al}_{2} \mathrm{O}_{3}$ ALD cycle (estimated by GPC in $0.1 \mathrm{~nm}$ ) leads to an improvement of the efficiency compared to the reference cells $(+13 \%)$. In particular, a significant increase in open circuit voltage $\left(\mathrm{V}_{\mathrm{OC}}\right)$ from 750 to $824 \mathrm{mV}(+10 \%)$ is observed, as expected when the recombination rate is reduced $(7-9,18-21)$. While the short circuit current $\left(\mathrm{J}_{\mathrm{SC}}\right)$ remains constant, also the fill factor (FF) exhibits an improvement $(+8 \%)$. Interestingly, increasing the number of the ALD cycles and consequently the thickness of the overlayer, a reduction on the short circuit current $\left(\mathrm{J}_{\mathrm{SC}}\right)$ is observed, decreasing the overall efficiency although the increment in the $\mathrm{V}_{\mathrm{OC}}$. A similar behaviour has been reported in the case of DSC technology (18). The increase in photovoltage was related to the shift of the quasi-Fermi level toward vacuum as a consequence of the improvement in the electron lifetime into the mesoporous layer. On the other hand, the increase of the energy barrier height at the interface $/ \mathrm{Al}_{2} \mathrm{O}_{3} /$ dye molecule with the increment of the ALD cycles was considered responsible for the decrease of injection of photo-generated electrons and consequently the reduction of the $\mathrm{J}_{\mathrm{SC}}(18)$. 
TABLE I. Photovoltaic performance of perovskite solar cells as function of the ALD cycle numbers.

\begin{tabular}{|c|c|c|c|c|}
\hline ALD cycles & $\begin{array}{c}\text { Efficiency } \\
(\%)\end{array}$ & $\begin{array}{c}\mathbf{J}_{\mathrm{SC}} \\
\left(\mathbf{m A ~ c m} \mathbf{c m}^{-2}\right)\end{array}$ & $\begin{array}{l}\mathbf{V}_{\mathrm{OC}} \\
(\mathbf{m V})\end{array}$ & $\begin{array}{l}\text { FF } \\
(\%)\end{array}$ \\
\hline 0 & $3.9 \pm 0.4$ & $-11.0 \pm 1.0$ & $749 \pm 4$ & $45.6 \pm 1.2$ \\
\hline 1 & $4.4 \pm 0.1$ & $-10.8 \pm 0.3$ & $824 \pm 13$ & $49.6 \pm 1.9$ \\
\hline 2 & $2.7 \pm 0.1$ & $-6.3 \pm 0.3$ & $884 \pm 13$ & $47.4 \pm 1.3$ \\
\hline 5 & $1.00 \pm 0.02$ & $-2.8 \pm 0.4$ & $890 \pm 5$ & $37.4 \pm 2.0$ \\
\hline 10 & $0.32 \pm 0.01$ & $-1.7 \pm 0.2$ & $852 \pm 7$ & $22.8 \pm 0.4$ \\
\hline
\end{tabular}

\section{Conclusion}

Atomic layer deposition was successfully applied for the fabrication of efficient functional layers in organo-lead halide perovskite solar cells in order to control the recombination interfaces inside the device architecture. The deposition of thin compact $\mathrm{TiO}_{2}$ layers via plasma-assisted ALD at $150{ }^{\circ} \mathrm{C}$ on ITO polymer surface enables the fabrication of efficient flexible devices over 5\%. The reduction of the charge transfer processes at the interface ITO and perovskite/HTM is fulfilled already with a $\mathrm{TiO}_{2}$ layer of $10 \mathrm{~nm}$. An $\mathrm{Al}_{2} \mathrm{O}_{3}$ layer was deposited via thermal ALD process at $150{ }^{\circ} \mathrm{C}$ to control the recombination mechanism at the interface between the mesoporous $\mathrm{TiO}_{2}$ and perovskite/HTM. The accurate control of the process in terms of growth per cycle $(0.1$ $\mathrm{nm} /$ cycle) was confirmed by TEM and the homogeneous distribution of the overlayer (in terms of $\mathrm{Al}$ content) was confirmed by XPS analysis. Preliminary investigation on the role of the $\mathrm{Al}_{2} \mathrm{O}_{3}$ thickness on the overall performance of perovskite devices highlights an improvement of the efficiencies $(+13 \%)$ only with a single ALD cycle. Increasing the number of the cycles a reduction of the performance has been observed, becoming drastic already at 5 cycles. These results demonstrate how ALD is a successful strategy for the nanoscale control of interfaces in mesoscopic solar cell.

\section{Acknowledgments}

Dr. M.A. Verheijen (TU/e) is acknowledged for the electron microscopy images. We also acknowledge the project ENERGY.2012.10.2.1 (NANOMATCELL, grant agreement no. 308997), th Netherlands Organization for Scientific Research (NWO, Aspasia program) and "Polo Solare Organico" Regione Lazio and the "DSSCX" MIURPRIN2010 for funding.

\section{References}

1. J.P. Van Delft, D. Garcia-Alonso and W.M.M Kessels., Semicon. Sci. Technol. 27, 074002 (2012)

2. G. Dingemans, W.M.M. Kessels, J. Vac. Sci. Technol. A, , 30, 040802 (2012).

3. N. Naghavi, D. Abou-Ras, N. Allsop, N. Barreau, S. Bücheler, A. Ennaoui, , C.H. Fischer, C. Guillen, D. Hariskos, J. Herrero, R. Klenk, K Kushiya, D. Lincot, , R. Menner, T. Nakada, C. Platzer-Björkman, S. Spiering, A.N. Tiwari, T. Törndahl, Prog. Photovoltaics Res. Appl., 11, 437 (2003). 
4. P. Gao, M. Gratzel, M.K. Nazeeruddin, Energy Environ. Sci., 7, 2448 (2014).

5. M. Gratzel, Nature Materials 13, 838 (2014).

6. B. Peng, G. Jungmann, C. Jager, D. Haarer, H.W. Schmidt, M. Thelakkat, Coordination Chemistry Reviews 248, 1479 (2004).

7. B.C. O' Regan, J.R. Durrant, P.M. Sommeling, N.J. Bakker, J. Phys. Chem. C, 111, 14001, (2007)

8. Y. Ogomi, K. Kukihara, S. Q., T. Toyoda, K. Yoshino, S. Pandey, H. Momose, S. Hayase, ChemPhysChem, 15, 1062 (2014)

9. G.S. Han, H.S. Chung, B.J. Kim, D.H. Kim, J.W. Lee, B.S. Swain, K. Mahmood, J.S. Yoo, N.G. Park, J.H. Lee, H.S. Jung, J. Mater. Chem. A, 3, 9160 (2015).

10. H.C.M. Knoops, S.E. Potts, A.A. Bol, and W. M. M. Kessels, Springer Handbook of Crystal Growth, Second Edi., vol. 39, no. 5. Elsevier B.V., 2010

11. S.D. Stranks, G.E. Eperon, G. Grancini, C. Menelaou, M.J.P. Alcocer, T. Leijtens, L.M. Herz, A. Petrozza, H.J. Snaith, Science 342, 341 (2013).

12. J Y. Wu, X. Yang, H. Chen, K. Zhang, C. Qin, J. Liu, W. Peng, A. Islam, E. Bi, F. Ye, M. Yin, P. Zhang, L. Han, Applied Physics Express 7, 052301 (2014)

13. W.M.M. Kessels S.B.S. Heil, E. Langereis, J.L. van Hemmen, H.C.H. Knoops, W. Keuning, M.C.M. van de Sanden, ECS Transactions, 3, 183 (2007).

14. V. Zardetto, A. Reale, A. Di Carlo, T.M. Brown, J. Polym. Sci. Part B Polym. Phys, 49, 638 (2011).

15. E. Palomares, J.N. Clifford, S.A. Haque, T. Lutz, J.R. Durrant, J. Am. Chem. Soc., 125, 475 (2003).

16. H.S. Jung, J.K. Lee, M. Nastasi, S.W. Lee, J.K. Kim, J.S. Park, K.S. Hong, H. Shin, Langmuir, 21, 10332 (2005).

17. V. Zardetto, F. Di Giacomo, T.M. Brown, A. Di Carlo, A. D’Epifanio, S. Licoccia, W.M.M. Kessels, M. Creatore, Materials and Matters, 9, 103, (2014)

18. T.C. Tien, F.M. Pan, L.P. Wang, C.H. Lee, Y.L. Tung, S.Y. Tsai, C. Lin, F.Y. Tsai, S.J. Chen, Nanotechnology, 20, 305201 (2009)

19. M. Shanmugam, M.F. Baroughi, D. Galipeau, Thin solid Films, 518, 2678 (2010).

20. A.K. Chandiran , N. Tetreault, R. Humphry-Baker, F. Kessler, E. Baranoff, C. Yi, M.K. Nazeeruddin, M. Grätzel, Nano Lett., 12, 3941 (2012).

21. A.K. Chandiran, A. Yella, M.T. Mayer, P. Gao, M.K. Nazeeruddin, M. Grätzel, Adv. Mater, 26, 4309 (2014).

22. A. Sarkar, S. E. Potts, S. A. Rushworth, F. Roozeboom, M.C.M. van de Sanden, W.M.M. Kessels, ECS Transactions, 33, 385 (2010).

23. F. Di Giacomo, V. Zardetto, A. D’Epifanio, S. Pescetelli F. Matteocci, S. Razza, A. Di Carlo, S. Licoccia, W.M.M. Kessels, M. Creatore, T.M. Brown, Adv. Energy Mater., 8, 1401808(2015).

24. F. Matteocci, S. Razza, F. Di Giacomo, S. Casaluci, G. Mincuzzi, T. M. Brown, A. D'Epifanio, S. Licoccia, A. Di Carlo, Phys. Chem. Chem. Phys., 16, 3918 (2014).

25. G.A.H. Wetzelaer, M. Scheepers, A.M. Sempere, C. Momblona, J. Ávila, H.J. Bolink, Adv. Mater., 27, 1837 (2015).

26. A.K. Chandiran, N. Tetreault, R. Humphry-Baker, F. Kessler, E. Baranoff, C. Yi, M.K. Nazeeruddin, M. Gratzel, Nano Lett. 12, 394 (2012). 